\title{
Screening of two glucocorticoids in non-prescription skin whitening creams purchased via internet in Iraq by HPLC method
}

\author{
Mohanad Naji Sahib* \\ Faculty of Pharmacy, Al-Rafidain University College, Baghdad, Iraq.
}

\section{ARTICLE INFO \\ Article history: \\ Received on: 22/02/2018 \\ Accepted on: 20/06/2018 \\ Available online: 30/07/2018}

\section{Key words:}

Betamethasone, Clobetasol, HPLC, validation, whitening cream.

\begin{abstract}
Using illegal lightening creams or preparations were reported widely throughout the world. Therefore, the present study aimed to the simultaneous determination of clobetasol 17-propionate (CB) and betamethasone 17-valerate (BM) in skin whitening creams purchased via internet from Iraqi market. The liquid chromatography was performed with Zorbax Eclipse Plus C18 $(150 \times 3.0 \mathrm{~mm}$ ID, $5 \mu \mathrm{m})$, mobile phase acetonitrile (70): water (30), the flow rate of $1 \mathrm{ml} /$ min and a UV detector at $240 \mathrm{~nm}$. The method was validated in terms of linearity, selectivity, precision, accuracy, limit of detection and quantification and stability of working solutions. The analytical method proved to be linear in the range of $1-40 \mu \mathrm{g} / \mathrm{ml}$ for both $\mathrm{CB}$ and BM. The limits of detection and quantification for CB and BM were $(0.024$ $\mu \mathrm{g} / \mathrm{ml}, 0.075 \mu \mathrm{g} / \mathrm{ml})$ and $(0.035 \mu \mathrm{g} / \mathrm{ml}, 0.107 \mu \mathrm{g} / \mathrm{ml})$, respectively, which revealed the sensitivity of the method. The precision, accuracy and stability study of working solutions of the method were between 0.52 to $1.93 \%, 97.87$ to $100.55 \%$ and 0.48 to $1.72 \%$, respectively. The results revealed that all purchased samples from beauty/cosmetic shops contained different levels of CB and/or BM. Moreover, the mixed preparations which purchased from the pharmacies also contained either CB or BM. The present study offers simple and sensitive analytical method to be used in the quality control laboratories and forensic point of view to identify illegal or counterfeit medicinal products or cosmetic preparations. Moreover, a new and restrict regulations must be implemented to ban the use of topical corticosteroids without prescription.
\end{abstract}

\section{INTRODUCTION}

Now a day, the easy access to internet provides consumers with different health services and support. Hence, upsurge the sale of medicine via internet without face to face interaction with a healthcare professional. This could lead to insufficient information about the safety and appropriate use of medicine or even potential hazard from their use (Bessell et al., 2003; Fittler et al., 2013). The revolution of using the internet and especially the social media is great in Iraq since 2007. The social media access and more precisely Facebook is now easier because it is offered free of charge by mobile network operators (Al-Hammadany and Heshmati, 2011). This lead to the growth of illegal cosmetics market or what is called black market via the internet.

Using illegal lightening creams or preparations were

\section{${ }^{*}$ Corresponding Author}

Mohanad Naji Sahib, Faculty of Pharmacy, Al-Rafidain University

College, 10052, Palestine Street, Baghdad, Iraq.

E-mail:mohanad_pharm@yahoo.com reported widely throughout the world (Del Giudice and Yves, 2002; Ly et al., 2007; AlGhamdi, 2010). Moreover, many articles documented the abuse of whitening creams among African or Asian populations or even in western countries (Huang et al., 2004; Nnoruka and Okoye, 2006; Olumide et al., 2008; Gaudiano et al., 2010; Nam et al., 2011). A recent study in Korea found that many cosmetic preparations manufactured there have been suspected to contain corticosteroid medicine (Nam et al., 2011). Misuse of corticosteroids drugs resulting with topical side effect when used for more than 3 weeks like skin atopy, masking of infections, acne as well as adrenal suppression (Harris and Hunter, 1988; Solomon et al., 1996). The adverse effects of topical corticosteroids have become more prevalent due to the introduction of high potency topical corticosteroids. These adverse effects were documented in the literature (Lagos and Maibach, 1998; Keane et al., 2001; Del Giudice and Yves, 2002; Mahé et al., 2003; Dey, 2014).

The previous study in Iraq showed that the most used topical corticosteroids were clobetasol 17-propionate $(\mathrm{CB})$ and betamethasone 17-valerate (BM) (Al Dhalimi and Al Jawahiry, 
2006). Due to their side effects, it is necessary to control their exposure to human by identifying or quantifying their levels in the advertised online skin lightening creams. Moreover, there was paucity in the literature regarding the abuse of corticosteroid drugs in whitening preparations purchase via internet in the Middle East region. Hence, the aim of this study was to develop simple and sensitive reverse-phase high-performance liquid chromatography analysis for simultaneous quantification of $\mathrm{CB}$ and $\mathrm{BM}$ in skin whitening creams purchased via internet from Iraqi market.

\section{MATERIALS AND METHODS}

\section{Purchasing samples}

Samples were purchased via the internet. The Google search was used with the keywords: mixed preparation, whitening cream, lightening cream and delivery to all areas of Baghdad city (the capital city of Iraq). Twenty-five beauty/cosmetic shops and pharmacies (15 and 10, respectively) were reached. The samples were purchased by local collaborators. The beauty shops vendors or the pharmacists were asked for the most effective preparation for whitening or lightening cream which suitable for all parts of the body (especially the face) to purchase. All beauty/cosmetic shops and 5 pharmacies offered mixed preparations while only 5 pharmacies offer already marketed preparations. The collaborators purchase 1 cream jar (50 gm) for the mixed preparations and the other marketed preparations (one purchase from each shop or pharmacy).

For method development, $\mathrm{CB}$ and $\mathrm{BM}$ creams were purchased from the local pharmacies because whitening preparations are most often creams. All purchased creams were coded as $\mathrm{C} 1$ to $\mathrm{C} 3$ and $\mathrm{B} 1$ to $\mathrm{B} 2$ for $\mathrm{CB}$ and $\mathrm{BM}$, respectively. The most available pharmaceutical products in Iraqi pharmacies were: Dermoden ${ }^{\circledR}$ (The State Company for Drugs Industry and Medical Appliances (SDI), Samarra, Iraq, C1), Dermovate ${ }^{\circledR}$ (GSK, Glaxo Operation UK Limited, Barnard Castle, UK, C2), Dermotan ${ }^{\circledR}$ (Ibn Hayyan Pharmaceuticals, Homs-Syria, C3) creams for CB. While the purchased pharmaceutical products for BM were: Betnovate ${ }^{\circledR}$ (GSK, Glaxo Operation UK Limited, Barnard Castle, UK, B1), Betnosam $^{\circledR}$ (The State Company for Drugs Industry and Medical Appliances (SDI), Samarra, Iraq B2) and Vasone ${ }^{\circledR}$ (Philadelphia Pharmaceuticals, Amman, Jordan).

\section{Instrumentation and chromatographic conditions}

The Chromatography was performed with a Shimadzu LC-20AD delivery pump (Shimadzu, Japan) equipped with UV/Vis detector (SPD-20A, Shimadzu, Japan), the SIL-20A HT prominence autosampler (Shimadzu, Japan), DGU20A3 prominence degasser (Shimadzu, Japan), fitted with 100 $\mu \mathrm{L}$ sample loop and the chromatointegrator (CBM-20A prominence communications bus model, Shimadzu, Japan). The chromatographic separation of the analytes was achieved at $40^{\circ} \mathrm{C}$ (CTO-10AS VP, Shimadzu column oven) using a Zorbax Eclipse Plus C18 $(150 \times 3.0 \mathrm{~mm}$ ID, $5 \mu \mathrm{m})$ (Agilent, USA). The mobile phase consisted of acetonitrile: water $(70: 30 \mathrm{v} / \mathrm{v})$ was filtered through a $0.45 \mu \mathrm{m}$ nylon membrane filter (Whatman, UK) under vacuum. The analysis was carried out at a flow rate of $1.0 \mathrm{ml} /$ min. The detector wavelength was set at $240 \mathrm{~nm}$. The injection volume was $20 \mu \mathrm{L}$. Acetonitrile and methanol were HPLC grade (J. T. Baker Analyzed, China). Clobetasol 17-propionate (purity $>98.0 \%$ ) and betamethasone 17 -valerate (purity $>97.0 \%$ ) standards were obtained from TCI (Tokyo Chemical Industry Co. LTD, Toshima KITA-KU, Tokyo, Japan).

\section{Standard solutions}

Stock solutions of $\mathrm{CB}$ and $\mathrm{BM}$ were prepared by dissolving $100 \mathrm{mg}$ of each in $50 \mathrm{ml}$ of methanol in order to give the concentration of $2 \mathrm{mg} / \mathrm{ml}$. The working standards for $\mathrm{CB}$ and BM (1 to $40 \mu \mathrm{g} / \mathrm{ml}$ ) were freshly prepared from the standard stock solution by serial dilution with the mobile phase.

\section{Sample solution preparation}

Twenty $\mathrm{ml}$ methanol was added to accurately weighted $1 \mathrm{gm}$ of the purchased creams then vortexed for $10 \mathrm{~min}$ and sonicated for $30 \mathrm{~min}$ until preparation dissolved. Thereafter, filter through $0.45 \mu \mathrm{m}$ Minisart microfilter (Sartorius, Germany) and made up the volume to $100 \mathrm{ml}$ with mobile phase.

\section{Method validation}

\section{Linearity}

To evaluate the linearity of the method, six calibration curves for $\mathrm{CB}$ and $\mathrm{BM}$ in the concentration range of 1 to $40 \mu \mathrm{g} /$ $\mathrm{ml}$ were prepared. The calibration curves were plotted for a peak area of the analytes against the corresponding concentrations $(\mu \mathrm{g} / \mathrm{ml})$ which obtained by linear regression analysis. Twenty $\mu \mathrm{L}$ aliquots were injected (six times) and eluted with the mobile phase under the reported chromatographic conditions. A recommended accepted criterion was regression coefficient $\left(R^{2}\right)$ is $\geq 0.999$ (CDER, 1994).

\section{Selectivity}

Due to unknown ingredients in the purchased samples, a preliminary study was done as suggested before (Kazakevich and Lobrutto, 2007). Spiked and unspiked samples were prepared for pharmaceutical preparations of $\mathrm{CB}$ and $\mathrm{BM}$ to determine the desired chromatographic conditions and to understand the behavior of the impurities in the analyte samples. Samples (C1 to $\mathrm{C} 3$ and B1 to B3) were prepared as sample solution method preparation (mentioned before) with the addition of $10 \mu \mathrm{g} / \mathrm{ml}$ CB or BM (spiked samples) or without the addition of standard solutions (unspiked samples).

\section{Precision}

The intra-day and inter-day precision were evaluated by analyzing quality control samples at low, medium and high concentrations (1, 10 and $40 \mu \mathrm{g} / \mathrm{ml})$ of $\mathrm{CB}$ and BM working standard solution. For the intra-day variation, sets of six replicates of quality control samples were analyzed on the same day and for the inter-day validation, six replicates of quality control samples were analyzed on three different days (Shaikh et al., 2008; Sahib, 2016). A recommended accepted criterion was \%RSD $<2.0$ (CDER, 1994).

\section{Accuracy}

A recovery study was carried out by standard additions method. All pharmaceutical preparations ( $\mathrm{C} 1$ to $\mathrm{C} 3$ and $\mathrm{B} 1$ to $\mathrm{B} 3$ ) 
were spiked with $\mathrm{CB}$ and $\mathrm{BM}$ in 80,100 , and $120 \%$ of the target test concentrations. Three replicate of each level was performed (Sahib, 2018). A recommended accepted criterion was \% RSD < 2.0 (CDER, 1994).

\section{Limits of detection and quantification}

The sensitivity of the method was determined based on the standard deviation of the response and the slope as described before (ICH, 2005; Sahib et al., 2011). The limit of detection (LOD) and quantification (LOQ) were calculated according to the following equations:

$$
\mathrm{LOD}=3.3 \sigma / \mathrm{S} ; \quad \mathrm{LOQ}=10 \sigma / \mathrm{S},
$$

where $\sigma=$ the standard deviation of the response; $S=$ the slope of the calibration curve.

\section{Solution stability}

Reference solutions were stored in the refrigerator for 14 days and re-analyzed in an injection sequence by employing freshly prepared standard solutions for a short-term stability. The above experiments were performed by using low, medium and high-quality control samples (Mohammadi et al., 2007; Sahib et al., 2010). A recommended accepted criterion was $\%$ RSD $<2.0$ (CDER, 1994).

\section{Method robustness}

The robustness of the suggested method was assessed as a function of altering acetonitrile: water volume ratio and temperature; the changes were over a range of $\pm 5 \%$ of the target experimental condition. The concentration of solution analyzed was $20 \mu \mathrm{g} / \mathrm{ml}(\mathrm{n}=6)$. A recommended accepted criterion was $\%$ RSD $<2.0$ (CDER, 1994).

\section{RESULTS AND DISCUSSION}

\section{Selectivity and system suitability}

The study revealed that the column used in this study showed good selectivity. The column Zorbax Eclipse plus C18 was selected as especially suited for this study as it can achieve excellent peak shape with greater resolution and accuracy (Figure 1A). Regarding system suitability, $10 \mu \mathrm{g} / \mathrm{ml}$ of the mixture of CB and BM were injected five times. The results of system suitability were shown in Table 1. The mean resolution value between $\mathrm{CB}$ and BM peaks was 2.8 (\%RSD: 0.01). All parameters were within acceptable values (CDER, 1994). Moreover, the results showed good peaks separation and resolution between $\mathrm{CB}$ and $\mathrm{BM}$ and the other excipients in their cream pharmaceutical formulations (Figure 1B and 1C). Moreover, no significant interfering peaks from the excipients were found at the specified retention time of the analysts in the purchased samples (Figure 1D). Hence, the developed analytical method was suitable and selective for $\mathrm{CB}$ and $\mathrm{BM}$ analysis in different formulations. Moreover, the method robustness results showed no marked changes in the chromatograms demonstrated with \%RSD range from 0.05 to 1.88. The low values of the \%RSD indicated the robustness of the suggested method.

Table 1: System suitability for simultaneous determination of Clobetasol 17- Propionate and Betamethasone 17-Valerate.

\begin{tabular}{|c|c|c|c|c|c|c|c|c|}
\hline \multirow[b]{2}{*}{ Injection } & \multicolumn{4}{|c|}{ Clobetasol 17- Propionate } & \multicolumn{4}{|c|}{ Betamethasone 17-Valerate } \\
\hline & $t_{R}$ & Area & $\mathbf{N}$ & Tailing factor & $t_{R}$ & Area & $\mathbf{N}$ & Tailing factor \\
\hline 1 & 6.056 & 414345 & 9507 & 1.13 & 6.697 & 384484 & 10152 & 1.109 \\
\hline 2 & 6.055 & 414144 & 9422 & 1.125 & 6.692 & 384155 & 9988 & 1.115 \\
\hline 3 & 6.056 & 413985 & 9376 & 1.127 & 6.698 & 384100 & 9876 & 1.103 \\
\hline 4 & 6.055 & 414104 & 9401 & 1.129 & 6.697 & 384330 & 10115 & 1.105 \\
\hline 5 & 6.053 & 413860 & 9366 & 1.122 & 6.695 & 384560 & 10028 & 1.114 \\
\hline Mean & 6.055 & 414087.6 & 9414.4 & 1.127 & 6.696 & 384325.8 & 10031.8 & 1.109 \\
\hline$\% \mathrm{RSD}$ & 0.020 & 0.044 & 0.597 & 0.285 & 0.036 & 0.052 & 1.087 & 0.479 \\
\hline
\end{tabular}

$\mathrm{t}_{\mathrm{R}}:$ retention time; $\mathrm{N}$ : theoretical plate number.

\section{Linearity}

The linear regression equation, correlation coefficient $\left(\mathrm{R}^{2}\right)$ and the limit of the detection and quantification in the analytical profile for $\mathrm{CB}$ and $\mathrm{BM}$ are listed in Table 2. The LOQ of this method allows the quantitation of both $\mathrm{CB}$ and $\mathrm{BM}$ even at ranges that are more typically addressed by the HPLC-Mass method.

\section{Precision}

Under the prescribed conditions, the precision is the closeness of agreement in the measurements of the same homogenous sample in different time intervals (ICH, 2005). The intra- and inter-day precisions (expressed as \% RSD) were a ranged from 0.52 to 1.93 . The $\% \mathrm{RSD}$ of the peak area of six replicates was found to be within acceptable limits (Épshtein, 2004; Reolon et al., 2018). Table 3 shows the precision study results.

Table 2: Calibration curve results summary for Clobetasol 17-Propionate and Betamethasone 17-Valerate, $\mathrm{n}=6$.

\begin{tabular}{ccc}
\hline Parameter & Clobetasol 17-Propionate & Betamethasone 17-Valerate \\
\hline Concentration $(\mu \mathrm{g} / \mathrm{ml})$ & $1,5,10,20,40$ & $1,5,10,20,40$ \\
Regression equation & $\mathrm{y}=42013 x-6017.1$ & $\mathrm{y}=36703 x+9988.2$ \\
$\mathrm{R}^{2}$ & 0.9999 & 0.9995 \\
LOD $(\mu \mathrm{g} / \mathrm{ml})$ & 0.024 & 0.035 \\
LOQ $(\mu \mathrm{g} / \mathrm{ml})$ & 0.075 & 0.107 \\
\hline
\end{tabular}

$\mathrm{R}^{2}$ : correlation coefficient; LOD: limit of detection; LOQ: limit of quantification. 

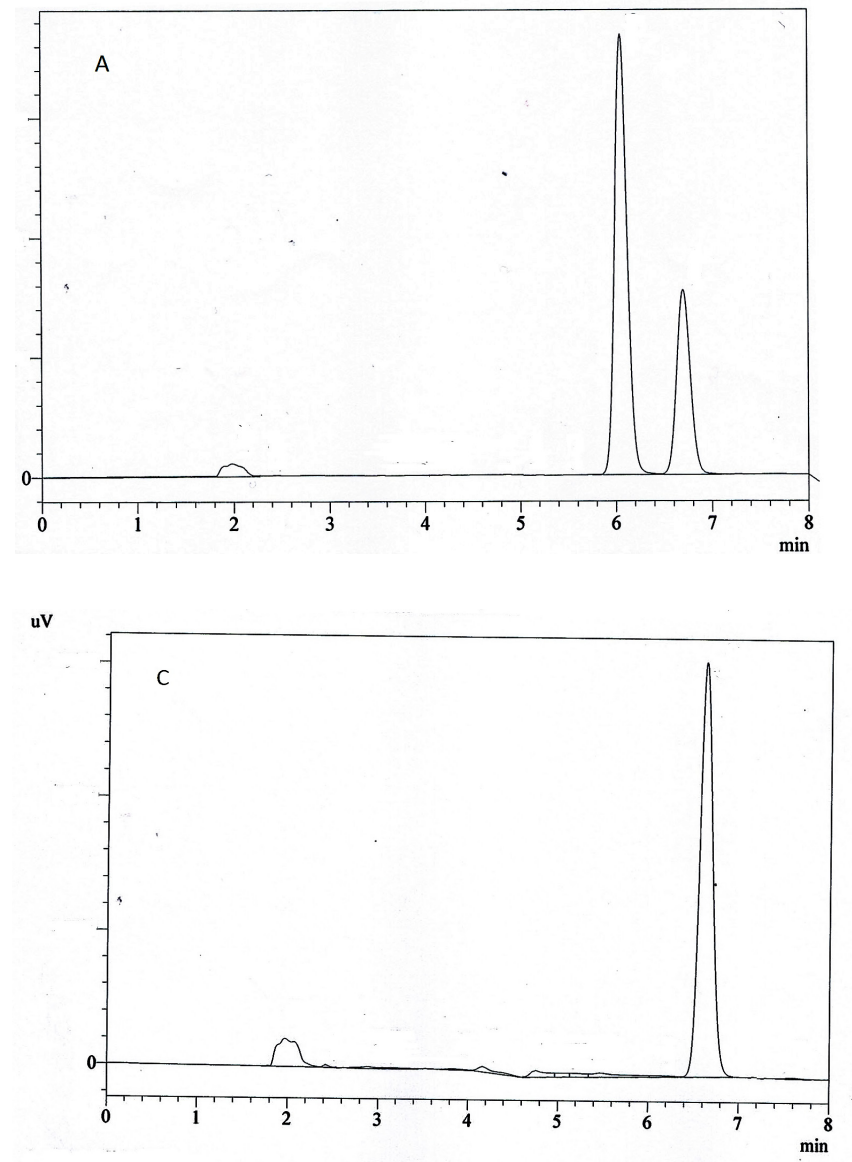

uV
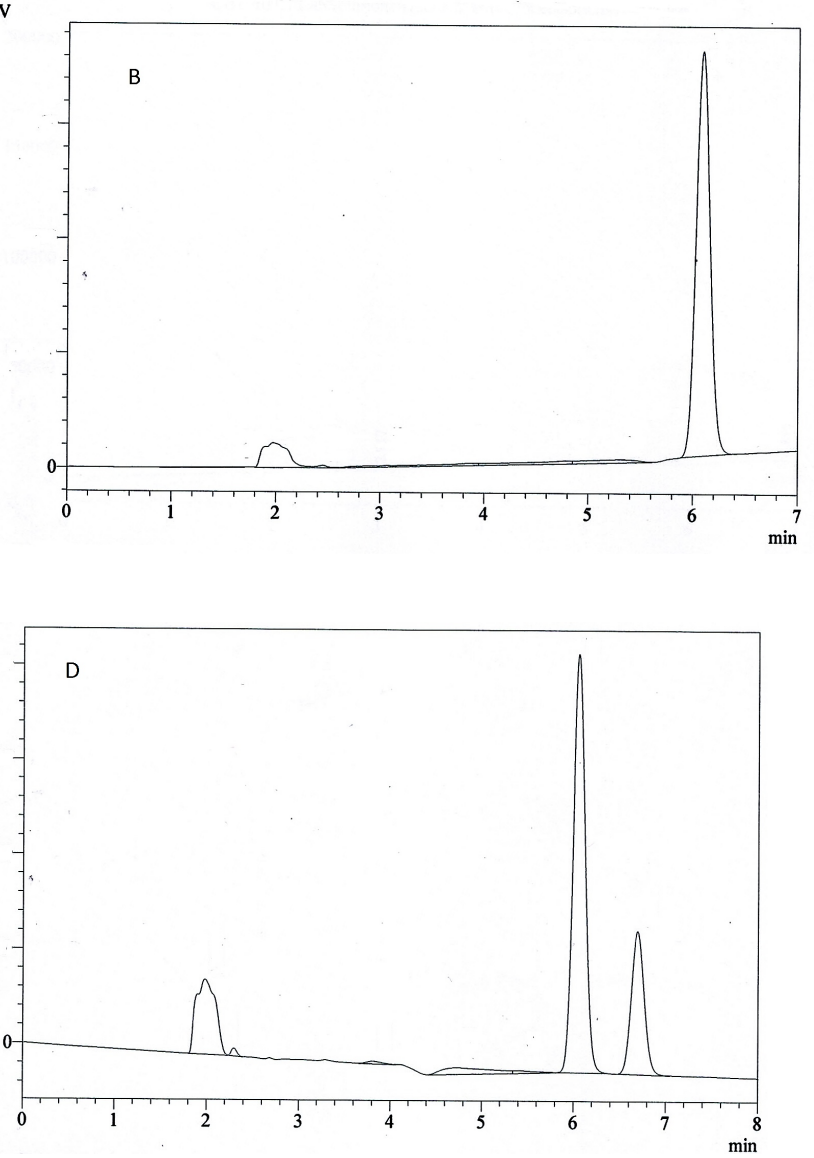

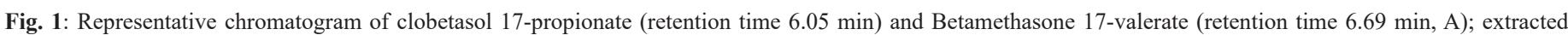

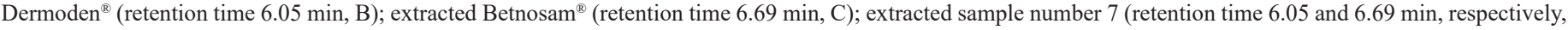
D).

Table 3: Intra-day and inter-day analysis and stability of the proposed analytical method of Clobetasol 17-Propionate and Betamethasone 17-Valerate.

\begin{tabular}{|c|c|c|c|c|}
\hline \multirow{2}{*}{ Compounds } & \multirow{2}{*}{$\begin{array}{c}\text { Theoretical } \\
\text { concentration } \\
(\mu \mathrm{g} / \mathrm{ml})\end{array}$} & \multicolumn{2}{|c|}{$\begin{array}{c}\text { Concentration mean } \pm \text { SD } \\
\text { (\%RSD) }\end{array}$} & \multirow{2}{*}{$\begin{array}{c}\text { Solution } \\
\text { stability } \\
\text { Concentration } \\
\text { mean } \pm \text { SD } \\
(\% \text { RSD })\end{array}$} \\
\hline & & Intra-day* & Inter-day** & \\
\hline \multirow{3}{*}{$\begin{array}{l}\text { Clobetasol } \\
\text { 17-Propionate }\end{array}$} & 1 & $\begin{array}{l}0.997 \pm 0.018 \\
(1.80)\end{array}$ & $\begin{array}{l}0.996 \pm 0.019 \\
(1.93)\end{array}$ & $\begin{array}{l}1.00 \pm 0.013 \\
\quad(1.38)\end{array}$ \\
\hline & 10 & $\begin{array}{l}9.988 \pm 0.121 \\
\quad(1.22)\end{array}$ & $\begin{array}{l}9.969 \pm 0.156 \\
\quad(1.569)\end{array}$ & $\begin{array}{c}9.933 \pm 0.140 \\
(1.41)\end{array}$ \\
\hline & 40 & $\begin{array}{c}39.996 \pm \\
0.238(0.59)\end{array}$ & $\begin{array}{c}39.917 \pm \\
0.273(0.685)\end{array}$ & $\begin{array}{c}39.903 \pm 0.293 \\
(0.73)\end{array}$ \\
\hline \multirow{3}{*}{$\begin{array}{l}\text { Betamethasone } \\
\text { 17-Valerate }\end{array}$} & 1 & $\begin{array}{c}0.994 \pm 0.017 \\
\quad(1.69)\end{array}$ & $\begin{array}{l}0.999 \pm 0.018 \\
\quad(1.88)\end{array}$ & $\begin{array}{c}0.990 \pm 0.015 \\
(1.57)\end{array}$ \\
\hline & 10 & $\begin{array}{c}10.043 \pm \\
0.131(1.31)\end{array}$ & $\begin{array}{l}9.907 \pm 0.156 \\
\quad(1.57)\end{array}$ & $\begin{array}{c}9.940 \pm 0.171 \\
(1.72)\end{array}$ \\
\hline & 40 & $\begin{array}{c}39.945 \pm \\
0.296(0.74)\end{array}$ & $\begin{array}{c}39.925 \pm \\
0.211(0.52)\end{array}$ & $\begin{array}{l}39.91 \pm 0.914 \\
(0.48)\end{array}$ \\
\hline
\end{tabular}

$* \mathrm{n}=6 ; * * \mathrm{n}=18$, six replicate in three different days.

\section{Accuracy}

The mean recovery percentages were a range between $97.87 \%$ and $100.55 \%$ (Table 4 ). In addition, the $\%$ RSD values were a range between $0.38 \%$ and $1.75 \%$. The results revealed that the proposed method was within the acceptable limits and accurate with negligible systematic error (Sahib et al., 2011; Prabaningdyah et al., 2017).

\section{Assay of the purchased whitening creams}

The results of the present study showed that all purchased products from the beauty/cosmetic shops were contained different levels of CB and/or BM(Table 5). Moreover, the mixed preparations which purchased from the pharmacies also contain either $\mathrm{CB}$ or BM. Only 5 pharmacies offered commercially available products. Two of them contain corticosteroid drug (Mometasone Furoate $0.1 \%$ ) and the other only contain bleaching/whitening agents.

This study showed that the use of topical corticosteroids is still uncontrolled in Iraqi community. The previous report from Iraq showed that $65.7 \%$ of the sample population were used topical corticosteroids for lightning effect (Al Dhalimi and Al Jawahiry, 2006). Other studies also showed a higher prevalence of using corticosteroids alone or in combinations with other whitening agents (Pitche et al., 1997; Wone et al., 2000; Adebajo, 2002; Nnoruka and Okoye, 2006; Saraswat et al., 2011). The Saudi Arabia study showed that $20.8 \%$ of the sample population was ready to use any whitening cream even the components were unknown if these cream give fast results (AlGhamdi, 2010). Other report showed that $25 \%$ of the sample population had used whitening products of unknown composition (Del Giudice and Yves, 2002). Moreover, 
other researchers showed that the population had the awareness of the adverse effect of whitening cream but they did not have the knowledge of these products or how it was used (Dlova et al., 2014). Hence, using corticosteroids as a whitening agent is a global problem which needs to be addressed.

Table 4: Recovery study results of spiked and unspiked samples of Clobetasol 17-Propionate and Betamethasone 17-Valerate pharmaceutical creams.

\begin{tabular}{|c|c|c|c|c|}
\hline Compound & Formula* & $\begin{array}{c}\text { Concentration } \\
\text { of the sample } \\
\text { (mg/gm), Mean } \\
\pm \mathrm{SD}^{* *}\end{array}$ & $\begin{array}{c}\text { Spiked } \\
\text { concentration } \\
(\mu \mathrm{g} / \mathrm{ml})\end{array}$ & $\begin{array}{c}\text { Recovery }(\%) \\
\text { Mean } \pm \text { SD } \\
(\% \text { RSD })\end{array}$ \\
\hline \multirow{12}{*}{$\begin{array}{c}\text { Clobetasol } \\
\text { 17-Propionate }\end{array}$} & $\mathrm{C} 1$ & $0.493 \pm 0.001$ & - & $\begin{array}{c}98.666 \pm 1.320 \\
(1.33)\end{array}$ \\
\hline & $\mathrm{C} 1$ & $0.887 \pm 0.013$ & 400 & $\begin{array}{c}98.65 \pm 1.554 \\
(1.57)\end{array}$ \\
\hline & $\mathrm{C} 1$ & $0.986 \pm 0.012$ & 500 & $\begin{array}{c}98.64 \pm 1.202 \\
(1.21)\end{array}$ \\
\hline & $\mathrm{C} 1$ & $1.090 \pm 0.001$ & 600 & $\begin{array}{c}99.16 \pm 0.876 \\
(0.88)\end{array}$ \\
\hline & $\mathrm{C} 2$ & $0.491 \pm 0.001$ & - & $\begin{array}{c}98.20 \pm 1.070 \\
(1.09)\end{array}$ \\
\hline & $\mathrm{C} 2$ & $0.885 \pm 0.010$ & 400 & $\begin{array}{c}98.35 \pm 1.194 \\
(1.21)\end{array}$ \\
\hline & $\mathrm{C} 2$ & $0.978 \pm 0.001$ & 500 & $\begin{array}{c}97.87 \pm 0.729 \\
(0.74)\end{array}$ \\
\hline & $\mathrm{C} 2$ & $1.090 \pm 0.001$ & 600 & $\begin{array}{c}99.15 \pm 0.888 \\
(0.89)\end{array}$ \\
\hline & $\mathrm{C} 3$ & $0.492 \pm 0.001$ & - & $\begin{array}{c}98.40 \pm 0.650 \\
(0.66)\end{array}$ \\
\hline & $\mathrm{C} 3$ & $0.881 \pm 0.001$ & 400 & $\begin{array}{c}97.91 \pm 1.043 \\
(1.06)\end{array}$ \\
\hline & $\mathrm{C} 3$ & $0.983 \pm 0.000$ & 500 & $\begin{array}{c}98.30 \pm 0.495 \\
(0.50)\end{array}$ \\
\hline & $\mathrm{C} 3$ & $1.091 \pm 0.013$ & 600 & $\begin{array}{c}99.18 \pm 1.233 \\
(1.24)\end{array}$ \\
\hline \multirow{12}{*}{$\begin{array}{l}\text { Betamethasone } \\
\text { 17-Valerate }\end{array}$} & B1 & $0.997 \pm 0.001$ & - & $\begin{array}{c}99.71 \pm 0.503 \\
(0.50)\end{array}$ \\
\hline & B1 & $1.767 \pm 0.025$ & 800 & $\begin{array}{c}98.21 \pm 1.422 \\
(1.44)\end{array}$ \\
\hline & B1 & $1.983 \pm 0.023$ & 1000 & $\begin{array}{c}99.18 \pm 1.172 \\
(1.18)\end{array}$ \\
\hline & B1 & $2.164 \pm 0.036$ & 1200 & $\begin{array}{c}98.39 \pm 1.662 \\
(1.68)\end{array}$ \\
\hline & B2 & $0.995 \pm 0.001$ & - & $\begin{array}{c}99.56 \pm 0.880 \\
(0.88)\end{array}$ \\
\hline & B2 & $1.786 \pm 0.031$ & 800 & $\begin{array}{c}99.27 \pm 1.741 \\
(1.75)\end{array}$ \\
\hline & B2 & $2.011 \pm 0.016$ & 1000 & $\begin{array}{c}100.55 \pm 0.828 \\
(0.82)\end{array}$ \\
\hline & B2 & $2.181 \pm 0.024$ & 1200 & $\begin{array}{c}99.16 \pm 1.094 \\
(1.10)\end{array}$ \\
\hline & B3 & $0.992 \pm 0.004$ & - & $\begin{array}{c}99.253 \pm 0.474 \\
(0.47)\end{array}$ \\
\hline & B3 & $1.781 \pm 0.028$ & 800 & $\begin{array}{c}98.96 \pm 1.560 \\
(1.57)\end{array}$ \\
\hline & B3 & $1.988 \pm 0.020$ & 1000 & $\begin{array}{c}99.40 \pm 1.028 \\
(1.03)\end{array}$ \\
\hline & B3 & $2.172 \pm 0.001$ & 1200 & $\begin{array}{c}98.75 \pm 0.384 \\
(0.38)\end{array}$ \\
\hline
\end{tabular}

${ }^{*} \mathrm{C} 1$ to $\mathrm{C} 3$ and $\mathrm{B} 1$ to $\mathrm{B} 3$ represent Clobetasol 17-Propionate and Betamethasone 17-Valerate in pharmaceutical creams; ** represent 3 replicates.
Table 5: Quantification of Clobetasol 17-Propionate and Betamethasone 17 -Valerate in the purchased samples via the internet.

\begin{tabular}{|c|c|c|c|}
\hline \multirow[b]{2}{*}{ Sample* } & \multirow[b]{2}{*}{ Type of sample** } & \multicolumn{2}{|c|}{ Amount detected $(\mathrm{mg} / \mathrm{g})$ cream } \\
\hline & & $\begin{array}{c}\text { Clobetasol } \\
\text { 17-Propionate }\end{array}$ & $\begin{array}{c}\text { Betamethasone } \\
\text { 17-Valerate }\end{array}$ \\
\hline 1 & Mixed preparation & 0.176 & 0.25 \\
\hline 2 & Mixed preparation & 0.265 & - \\
\hline 3 & Mixed preparation & - & 0.564 \\
\hline 4 & Mixed preparation & 0.187 & 0.442 \\
\hline 5 & Mixed preparation & 0.364 & - \\
\hline 6 & Mixed preparation & - & 0.477 \\
\hline 7 & Mixed preparation & 0.331 & 0.322 \\
\hline 8 & Mixed preparation & 0.162 & - \\
\hline 9 & Mixed preparation & 0.364 & - \\
\hline 10 & Mixed preparation & 0.411 & - \\
\hline 11 & Mixed preparation & 0.262 & - \\
\hline 12 & Mixed preparation & - & 0.775 \\
\hline 13 & Mixed preparation & - & 0.433 \\
\hline 14 & Mixed preparation & 0.210 & 0.339 \\
\hline 15 & Mixed preparation & 0.243 & - \\
\hline 16 & Mixed preparation & 0.321 & - \\
\hline 17 & Mixed preparation & 0.211 & - \\
\hline 18 & Mixed preparation & 0.342 & - \\
\hline 19 & Mixed preparation & 0.211 & - \\
\hline 20 & Mixed preparation & 0.265 & - \\
\hline 21 & Melanot $^{\mathbb{1}}$ & - & - \\
\hline 22 & Philaquin Forte ${ }^{\circledR}$ & - & - \\
\hline 23 & Eldoquin Forte ${ }^{\circledR}$ & - & - \\
\hline 24 & Melacare $^{\circledR}$ & - & - \\
\hline 25 & Elocon $^{\circledR}$ & - & - \\
\hline
\end{tabular}

*Samples 1 to 15 and samples 16 to 25 were purchased from Beauty/cosmetic shops and pharmacies, respectively. ${ }^{* *}$ Melanot $^{\mathbb{B}}$ (Glycolic acid 10\%, Arbutin 5\%, Kojic acid 2\%; Forte Pharma Laboratories, Monaco, France); Philaquin Forte $^{\circledR}$ (Hydroquinone 4\%, Philadelphia Pharmaceuticals, Amman, Jordan); Eldoquin Forte ${ }^{\circledast}$ (Hydroquinone 4\%, ICN Pharmaceuticals Inc, California, USA); Melacare ${ }^{\circledR}$ (Hydroquinone $2 \%$, Tretinoin $0.025 \%$, Mometasone Furoate $0.1 \%$, Ajanta Pharm Limited, Mumbai, India); Elocon ${ }^{\circledR}$ (Mometasone Furoate $0.1 \%$, Universal Pharmaceutical Industry, Damascus, Syria).

Furthermore, the results revealed that using corticosteroids as whitening or depigmenting agent is still a common practice among Iraqi pharmacists. The result is consistent with the previous report in that the pharmacists responsible for the incorrect use or abuse of the medications (Al Dhalimi and Al Jawahiry, 2006). The present study showed another way to abuse medications by black market via the internet and, unfortunately, the pharmacists were involved in that. The present result was in agreement with another report. Al Dhalimi et al. showed that other persons beside the pharmacists were responsible for corticosteroids abuse like paramedical personnel $(27 \%)$, self, friend or family member $(20 \%)$, street vendor $(20 \%)$, physician (11\%) and dermatologist (4\%) (Al Dhalimi and Al Jawahiry, 2006). 
Therefore, the community based educational program is an urgent need to increase the knowledge and practice regarding the use of skin lightening agents. In addition, psychological aspects must be addressed or evaluated for this purpose because hyperpigmentation disorders have a great impact on the motivation of using lightening preparations, as well as, the quality of life (Ladizinski et al., 2011).

\section{CONCLUSION}

The present study offers simple and sensitive analytical method to be used in the quality control laboratories and forensic point of view to identify illegal or counterfeit medicinal products or cosmetic preparations. In addition, the simultaneous determination of $\mathrm{CB}$ and BM could potentially reduce the laboratory supply costs associated with a testing method for individual drugs. Moreover, a new and restrict regulations must be implemented to ban the use or purchase of topical corticosteroids without prescription.

\section{CONFLICTS OF INTERESTS}

The author has none to declare.

\section{FUNDING SOURCES}

The author has none to declare.

\section{REFERENCES}

Adebajo S. An epidemiological survey of the use of cosmetic skin lightening cosmetics among traders in Lagos, Nigeria. Mercury, 2002; 5:43-8.

Al-Hammadany FH, Heshmati A. Determinants of Internet use in Iraq. Int J Commun, 2011; 5:23.

Al Dhalimi M, Al Jawahiry N. Misuse of topical corticosteroids: a clinical study in an Iraqi hospital. East Mediterr Health J, 2006; 12:847852 .

Alghamdi KM. The use of topical bleaching agents among women: a cross-sectional study of knowledge, attitude and practices. J Eur Acad Dermatol Venereol, 2010; 24:1214-1219.

Bessell TL, Anderson JN, Silagy CA, Sansom LN, Hiller JE. Surfing, self-medicating and safety: buying non-prescription and complementary medicines via the internet. Qual Saf Health Care, 2003; 12:88-92.

CDER (Center for Drug Evaluation and Research. 1994. Reviewer Guidance: Validation of chromatographic methods. Washington. [ONLINE] Available at: https://www.fda.gov/downloads/drugs/guidances/ ucm134409.pdf [Accessed 01 July 2017].

Del Giudice P, Yves P. The widespread use of skin lightening creams in Senegal: a persistent public health problem in West Africa. Int J Dermatol, 2002; 41:69-72.

Dey VK. Misuse of topical corticosteroids: A clinical study of adverse effects. Indian Dermatol Online J, 2014; 5:436-440.

Dlova N, Hamed SH, Tsoka-Gwegweni J, Grobler A, Hift R. Women's perceptions of the benefits and risks of skin-lightening creams in two South African communities. J Cosmet Dermatol, 2014; 13:236-241.

Épshtein NA. Validation of HPLC Techniques for Pharmaceutical Analysis. Pharm Chem J, 2004; 38:212-228.

Fittler A, Lankó E, Brachmann B, Botz L. Behaviour analysis of patients who purchase medicines on the internet: can hospital pharmacists facilitate online medication safety? Eur J Hosp Pharm Sci Pract, 2013; 20:812.

Gaudiano MC, Lucente D, Antoniella E, Bertocchi P, Muleri N, Manna L, Bartolomei M, Alimonti S, Valvo L, Rodomonte AL. "For export only" medicines come back to Europe: A RP-LC method for the screening of six glucocorticoids in illegal and counterfeit anti-inflammatory and lightening creams. J Pharm Biomed Anal, 2010; 53:158-164.

Harris D, Hunter J. The use and abuse of 0.05 per cent clobetasol propionate in dermatology. Dermatol Clin, 1988; 6:643-647.

Huang S-C, Lin C-C, Huang M-C, Wen K-C. Simultaneous determination of magnesium ascorbyl phosphate, ascorbyl glucoside, kojic acid, arbutin and hydroquinone in skin whitening cosmetics by HPLC. J Food Drug Anal, 2004; 12:13-18.

ICH. 2005. Validation of analytical procedures: text and methodology Q2 (R1). [ONLINE] Available at: http://www.ema. europa.eu/docs/en GB/document library/Scientific guideline/2009/09/ WC500002662.pdf [Accessed 01 July 2017].

Kazakevich YV, Lobrutto R. 2007. HPLC for pharmaceutical scientists. New Jersey, USA: John Wiley \& Sons.

Keane FM, Munn SE, Taylor NF, Du Vivier AWP. Unregulated use of clobetasol propionate. Br J Dermatol, 2001; 144:1095-1096.

Ladizinski B, Mistry N, Kundu RV. Widespread Use of Toxic Skin Lightening Compounds: Medical and Psychosocial Aspects. Dermatol Clin, 2011; 29:111-123.

Lagos B, Maibach H. Frequency of application of topical corticosteroids: an overview. Br J Dermatol, 1998; 139:763-766.

Ly F, Soko AS, Dione DA, Niang SO, Kane A, Bocoum TI, Dieng MT, Ndiaye B. Aesthetic problems associated with the cosmetic use of bleaching products. Int J Dermatol, 2007; 46:15-17.

Mahé A, Ly F, Aymard G, Dangou JM. Skin diseases associated with the cosmetic use of bleaching products in women from Dakar, Senegal. Br J Dermatol, 2003; 148:493-500.

Mohammadi A, Rezanour N, Ansari Dogaheh M, Ghorbani Bidkorbeh F, Hashem M, Walker RB. A stability-indicating high performance liquid chromatographic (HPLC) assay for the simultaneous determination of atorvastatin and amlodipine in commercial tablets. J Chromatogr B, 2007; 846:215-221.

Nam YS, Kwon IK, Lee K-B. Monitoring of clobetasol propionate and betamethasone dipropionate as undeclared steroids in cosmetic products manufactured in Korea. Forensic Sci Int, 2011; 210:144148 .

Nnoruka E, Okoye O. Topical steroid abuse: its use as a depigmenting agent. J Natl Med Assoc, 2006; 98:934-939.

Olumide YM, Akinkugbe AO, Altraide D, Mohammed T, Ahamefule N, Ayanlowo S, Onyekonwu C, Essen N. Complications of chronic use of skin lightening cosmetics. Int J Dermatol, 2008; 47:344-353.

Pitche P, Afanou A, Amanga Y, Tchangai-Walla K. Prevalence of skin disorders associated with the use of bleaching cosmetics by Lome women. Sante, 1997; 7:161-164.

Prabaningdyah NK, Riyanto S, Rohman A, Siregar C. Application of HPLC and response surface methodology for simultaneous determination of curcumin and desmethoxy curcumin in Curcuma syrup formulation. J Appl Pharm Sci, 2017; 7:58-64.

Reolon JB, Brustolin M, Haas SE, Bender EA, Malesuik MD, Colomé LM. Development and validation of high-performance liquid chromatography method for simultaneous determination of acyclovir and curcumin in polymeric microparticles. J Appl Pharm Sci, 2018; 8:136-141.

Sahib M. Content variations of carbamazepine tablets in Iraqi community pharmacies: application of high-performance liquid chromatography assay method. Asian J Pharm Clin Res, 2018; 11:117-120.

Sahib MN. Development and Validation of A Reverse-Phase High Performance Liquid Chromatography Analysis for Paracetamol in Tablets Formulations. J Al-Rafidain University College, 2016; 37:301-315. Sahib MN, Darwis Y, Khiang PK, Fung Tan YT. Aerodynamic characterization of beclomethasone dipropionate from beclate-50 inhaler $\mathbb{}$ by HPLC-UV. J Liq Chromatogr Relat Technol, 2011; 34:613-621.

Sahib MN, Darwis Y, Khiang PK, Tan YTF. Aerodynamic characterization of marketed inhaler dosage forms: High performance liquid chromatography assay method for the determination of budesonide. Afr J Pharm Pharmacol, 2010; 4:878-884.

Saraswat A, Lahiri K, Chatterjee M, Barua S, Coondoo A, Mittal A, Panda S, Rajagopalan M, Sharma R, Abraham A. Topical corticosteroid 
abuse on the face: A prospective, multicenter study of dermatology outpatients. Indian J Dermatol Venereol Leprol, 2011; 77:160-166.

Shaikh KA, Patil SD, Devkhile AB. Development and validation of a reversed-phase HPLC method for simultaneous estimation of ambroxol hydrochloride and azithromycin in tablet dosage form. J Pharm Biomed Anal, 2008; 48:1481-1484.

Solomon B, Glass A, Rabbin P. Tinea incognito and" over-thecounter" potent topical steroids. Cutis, 1996; 58:295-296.

Wone I, Tal-Dia A, Diallo O, Badiane M, Touré K, Diallo I. Prevalence of the use of skin bleaching cosmetics in two areas in Dakar (Senegal). Dakar Med, 2000; 45:154-157.

How to cite this article:

Sahib MN. Screening of two glucocorticoids in non-prescription skin whitening creams purchased via internet in Iraq by HPLC method. J App Pharm Sci, 2018; 8(07): 078-084. 